\title{
ANALISA DAN PERANCANGAN APLIKASI POINT OF SALE (POS) UNTUK MENDUKUNG MANAJEMEN HUBUNGAN PELANGGAN
}

\author{
Silvester Dian Handy Permana ${ }^{1}$, Faisal $^{2}$ \\ ${ }^{1,2}$ Fakultas Telematika Universitas Trilogi \\ Email: ${ }^{1}$ handy@universitas-trilogi.ac.id, ${ }^{2}$ faisalpiliang@ universitas-trilogi.ac.id
}

(Naskah masuk: 29 Januari 2015, diterima untuk diterbitkan: 17 Februari 2015)

\begin{abstract}
Abstrak
Perkembangan dunia bisnis mendorong perusahaan untuk selalu berusaha meningkatkan kualitas produk dan pelayanan kepada konsumen. Layanan pembelian barang dapat dilakuan secara elektronik dan juga dapat dilakukan secara online atau electronic commerce. Penerapan solusi bisnis tersebut merupakan komitmen dalam meningkatkan keunggulan kompetitif pelanggan korporatnya dalam hal efisiensi, efektivitas, kinerja, serta pengembangan bisnis. Adapun tujuan dari penelitian ini yaitu melakukan analisis dan perancangan aplikasi point of sale (POS) untuk mendukung sistem layanan pembelian yang dapat membantu para pengusaha kecil dan menengah dalam pengelolaan data. Pembuatan aplikasi POS ini dimulai dari pengumpulan seluruh data-data yang dibutuhkan dengan menggunakan metode observasi dan wawancara, perancangan model aplikasi dengan pendekatan diagram berbasis obyek dengan alat bantu perancangan aplikasi berupa diagram alir / flowchart dan Unified Modeling Language (UML) hingga diimplementasikannya aplikasi POS ini. Dengan diterapkannya aplikasi point of sales (POS) ini dapat membantu tugas-tugas pihak-pihak terkait atau seluruh stake-holder yang berhubungan langsung dengan aplikasi POS ini.
\end{abstract}

Kata kunci: Manajemen hubungan pelanggan, point of sales, electronic commerce, Unified Modeling Language

\begin{abstract}
The development of the business prompted the company to always strive to improve the quality of products and services to consumers. The service can purchase goods was done electronically and can also be done online or electronic commerce. Implementation of business solutions is a commitment to improve its corporate customers a competitive advantage in terms of efficiency, effectiveness, performance, and business development. The research purpose is to analyze and design the application point of sale (POS) system to support the purchase of services that can help small and medium entrepreneurs in data management. The application point of sale (POS) system develop is started from collecting all the data required by using observation and interviews method, the application model design using object-oriented diagram approach, the design tools using flowchart and Unified Modeling Language (UML) till the implementation of this POS application. The implementation of the application point of sales (POS) can help tasks related parties or all of the stakeholders that are directly related to this POS application.
\end{abstract}

Keywords: Customer relation management, point of sales, electronic commerce, Unified Modeling Language

\section{PENDAHULUAN}

Perkembangan dunia bisnis yang semakin pesat dan persaingan usaha yang kian ketat mendorong perusahaan untuk selalu berusaha meningkatkan kualitas produk dan pelayanan kepada konsumen, agar bisa tetap bertahan bahkan dapat memenangkan persaingan usaha. Kepuasan konsumen dalam hal pemenuhan kebutuhan dan layanan penjualan menjadi konsep keberhasilan dalam dunia bisnis.

Saat ini pemilihan layanan pembelian barang dapat dilakuan secara elektronik dan juga dapat dilakukan secara online atau electronic commerce dan telah menjadi sarana paling popular. Layanan publik melalui media elektronik diatas bisa menjadi sarana praktis, mudah dan murah. Informasi yang diberikan pun bisa langsung dirasakan masyarakat luas baik oleh dunia usaha maupun bagi masyarakat umumnya.

Layanan pembelian barang secara elektronik semakin menggeliat, banyak sarana beserta prasarana layanan pembelian yang menyediakan barang mereka untuk bisa dibeli secara elektronik. Namun demikian, masalah keamanan, pelayanan serta kurangnya pemahaman atas proses jual beli elekronik masih menjadi persoalan di dunia jual beli secara elekronik di Indonesia.

Pada dunia usaha, adanya layanan elektronik salah satunya akan memberikan kemudahan dalam pelayanan kepada pelanggan. Layanan elektronik ini dapat diterapkan dan dimanfaatkan pada berbagai bidang termasuk layanan pembelian barang. Penerapan solusi bisnis tersebut merupakan komitmen dalam meningkatkan keunggulan kompetitif pelanggan korporatnya dalam hal efisiensi, efektivitas, kinerja, serta pengembangan 
bisnis. Hal ini tentunya menjadi bagian dari upaya dalam peningkatan kualitas layanan sekaligus membawa manfaat bagi pelayanan pelanggan.

Internet adalah salah satu teknologi yang sangat pesat perkembangannya dan sudah merupakan simbol dari cara berkomunikasi secara bebas, tanpa dibatasi ruang, jarak dan waktu. Informasi yang disajikan pun tidak terbatas pada teks dan gambar saja. Melainkan juga suara dan animasi gambar yang membuatnya menjadi interaktif. Dengan ditunjang oleh berbagai kelebihan yang dimiliki oleh internet, diantaranya biaya koneksi yang relatif terjangkau dan ketersediaan informasi yang tidak terbatas, internet kini menjadi alternatif utama untuk memenuhi segala kebutuhan terutama kebutuhan akan informasi.

Berdasarkan hal tersebut, maka dirancanglah suatu sistem layanan pembelian yang terkomputerisasi untuk mempermudah perusahaan dalam mengelola pelanggannya, sekaligus mendukung kegiatan point of sales dan penyetokan barang. Adapun tujuan dari penelitian ini yaitu melakukan analisis dan perancangan aplikasi point of sale (POS) untuk mendukung sistem layanan pembelian yang dapat membantu para pengusaha kecil dan menengah dalam pengelolaan data.

\section{TINJAUAN PUSTAKA}

\subsection{Point of sale (POS)}

Pengertian dari Point Of Sale (POS) yaitu merupakan kegiatan yang berorientasi pada penjualan serta sistem yang membantu proses transaksi. Setiap POS terdiri dari hardware berupa (Terminal/PC, Receipt Printer, Cash Drawer, Terminal pembayaran, Barcode Scanner) dan software berupa (Inventory Management, Pelaporan, Purchasing, Customer Management, Standar Keamanan Transaksi, Return Processing) dimana kedua komponen tersebut digunakan untuk setiap proses transaksi. POS akan menjadi sangat penting di dunia bisnis karena POS diibaratkan berupa terminal uang dimana tempat menerima pembayaran dari pembeli kepada pedagang, karena pembayaran tersebut merupakan indikator bagi pebisnis untuk mengukur tingkat pendapatan mereka (Axopos, 2015).

\subsection{Konsep Sistem}

Sistem merupakan suatu jaringan prosedurprosedur yang saling berhubungan dan atau saling berkumpul untuk melakukan suatu interaksi berupa suatu kegiatan atau suatu proses kerja dalam menyelesaikan suatu tujuan dari sistem tersebut. Prosedur merupakan suatu urutan dari tindakan atau aksi yang disusun untuk menjamin adanya perlakuan yang seragam terhadap kejadian yang berlangsung berulang-ulang. Maksud dari adanya sistem adalah untuk mencapai tujuan pokok dari sistem tersebut.
Tujuan pokok ini akan terlaksana apabila terdapat elemen-elemen dan prosedur-prosedur di dalam sistem yang saling berhubungan membentuk satu kesatuan (Jogiyanto, 2008).

\subsection{Penelitian Terkait}

Kajian penelitian: Analisis dan Perancangan Sistem Informasi Toko Dika (Silvester Dian Handy Permana. 2014). Dengan adanya "Sistem Informasi Toko Dika" ini, pembukuan yang ada di Toko Dika dapat terkomputerisasi dengan baik sehingga dapat dikarenakan mengurangi waktu mencari suatu informasi, meningkatkan kontrol keuangan, meningkatkan service level, mengurangi kebutuhan sumber daya manusia, dan mengurangi penyimpanan buku yang besar.

* Kajian penelitian: Analisis Dan Perancangan Aplikasi Point Of Sales Yang Terhubung Dengan Electronic Data Capture (Petrus Hartono, 2009), dengan tujuan untuk melakukan pengembangan aplikasi Point Of Sales (POS) yang terhubung dengan Electronic Data Capture untuk mengurangi kesalahan yang terjadi dalam penggunaan POS dan EDC dalam pembayaran dengan kartu.

* Kajian penelitian: Perancangan Aplikasi Point Of Sales Berbasiskan Customer Relationship Management Pada Toko Buku Notre-Dame (Gintoro, 2010), dengan tujuan untuk memberikan beberapa solusi bagi masalah yang dihadapi Toko Buku Notre-Dame, seperti pencatatan transaksi yang lebih mudah, pengelolaan data pelanggan yang lebih rapi dan tidak mungkin hilang, serta pelaporan yang lebih praktis dan terperinci.

* Kajian penelitian: Rancangan \& Implementasi Point Of Sales (POS) Berbasis Web Pada Distro Previous (Imanuel Abdi Ridarta Ginting, 2011), dengan tujuan untuk memudahkan dalam pencatatan transaksi penjualan.

* Kajian penelitian: Perancangan Sistem Point of Sales (POS) Pada Toko Koperasi Jasa Pakarti Semarang (PT. Jasa Marga Tbk Cabang Semarang) (Widianto, 2013), dengan tujuan untuk memberikan bantuan dalam proses pelayanan atau proses transaksi penjualan dan pembelian di Toko Koperasi Jasa Pakarti Semarang.

* Kajian penelitian: Pengaruh Penerapan Aplikasi POS (Point Of Sale) Berbasis Komputer Terhadap Kecepatan Proses Transaksi Penjualan Dan Pembelian (haris klana sanif, 2010), dengan tujuan untuk memberikan bantuan dalam pengambilan keputusan dan menentukan langkah-langkah yang akan ditempuh oleh perusahaan dalam melaksanakan aktivitas proses penjualan dan pembelian dengan baik dan benar. 
* Kajian penelitian: Analisis dan Implementasi Sistem Informasi Pembelian dan Penjualan Menggunakan Model Reuse-Oriented Berbasis Framework AHADPOS (Trio Rulia Winda Afrianto, 2010), dengan tujuan untuk memberikan bantuan dalam mengelola data jual beli secara terinci sehingga dapat digunakan sebagai dasar penentuan strategi yang akan digunakan dimasa yang akan datang.

* Kajian penelitian: Perancangan Sistem Informasi Point Of Sale (POS) Pada PD.Tokyo (Novita, 2010), dengan tujuan untuk memberikan bantuan dalam mempermudah, mempercepat dan mengurangi tingkat kesalahan dalam pengelolaan baik data penjualan, pembelian, stok, cash flow dan laporan laba rugi.

\section{METODE}

Analisa dan perancangan aplikasi point of sales (POS) yang baik adalah aplikasi yang mencakup semua scope/ruang lingkup yang ditentukan. Tentu saja aspek integrasi antara bagian dalam suatu aplikasi POS sangatlah penting, dimana data dalam aplikasi POS saling berinteraksi dalam meningkatkan kecepatan, akurasi dan kemudahan.

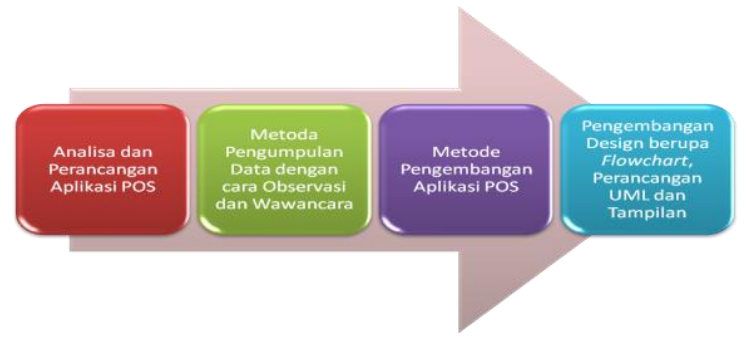

Gambar 1. Kerangka Konsep Aplikasi POS

Gambar 1 diatas menujukkan kerangka konsep analisa dan perancangan aplikasi POS. Kerangka konsep ini menggambarkan bagaimana proses aplikasi POS ini dibuat. Pembuatan aplikasi POS ini dimulai dari pengumpulan data dengan observasi dan wawancara hingga diimplementasikannya aplikasi POS ini. Dengan adanya proses yang baik inilah diharapkan aplikasi POS yang dibangun tepat guna dan dapat mengakomodasi seluruh kegiatan/ proses bisnis yang terjadi.

\subsection{Analisis dan Perancangan}

Skema pemetaan hubungan input, proses dan output dapat terlihat pada gambar dibawah ini. Input yaitu data yang ada yang akan dimasukkan kedalam aplikasi, proses yaitu hal yang sedang berlangsung dan berkaitan dengan bisnis proses yang ada dan output yang meliputi laporan dari setiap kegiatan yang ada.

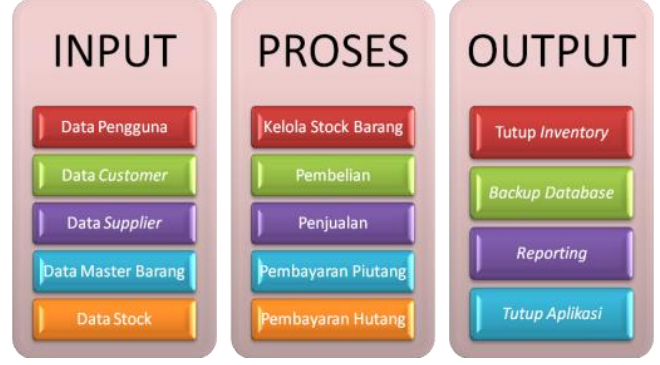

Gambar 2. Skema Pemetaan Aplikasi POS

Dari gambar diatas, dapat dilihat antara input, proses dan output saling berinteraksi. Hal tersebut didapatkan tentunya dalam pengumpulan kebutuhan sistem (requirement gathering) melalui hasil observasi dan wawancara.

\subsection{Perancangan Sistem}

Perancangan sistem yang akan digunakan dalam penelitian ini adalah dengan menggunakan pendekatan diagram berbasis obyek dengan alat bantu perancangan aplikasi berupa diagram alir / flowchart dan Unified Modeling Language (UML) yaitu berupa Use Case Diagram, Class Diagram, Activity Diagram dan Sequence Diagram.

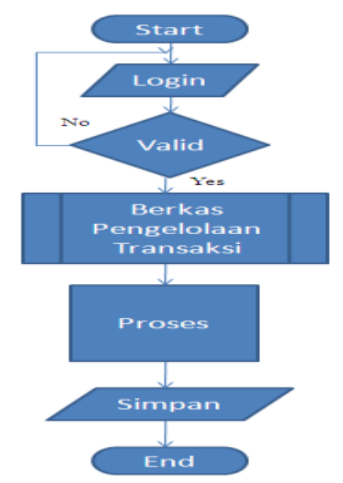

Gambar 3. Diagram alir Aplikasi POS

Pada Gambar 3 diatas, diagram alir / flowchart diatas terlihat bahwa aliran rancangan aplikasi dimulai dengan masuk kedalam aplikasi dengan fasilitas login. Jika proses login tersebut berhasil maka aplikasi POS dapat dibuka dan dapat melakukan proses yang diinginkan berupa Berkas, Pengelolaan dan Transaksi.

\subsection{Perancangan UML}

Penggambaran perancangan Unified Modeling Language (UML) berupa Use Case Diagram, Class Diagram, Activity Diagram dan Sequence Diagram dapat terlihat pada gambar dibawah ini. 


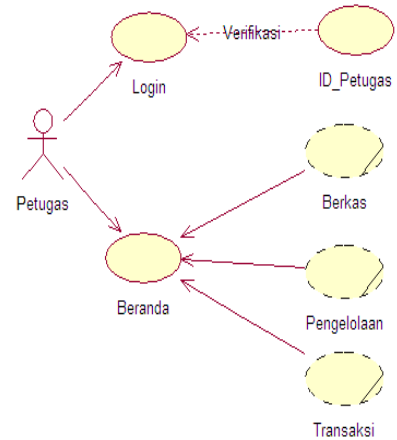

Gambar 4. Use Case Diagram Aplikasi POS

Pada gambar 4 diatas dapat dilihat bahwa aktor adalah seorang Petugas. Petugas ini dapat menjalankan aplikasi dengan melakukan login terlebih dahulu. Setelah melakukan login, Petugas memasuki bagian beranda dimana dapat melakukan aktifitas pengelolaan transaksi disana.

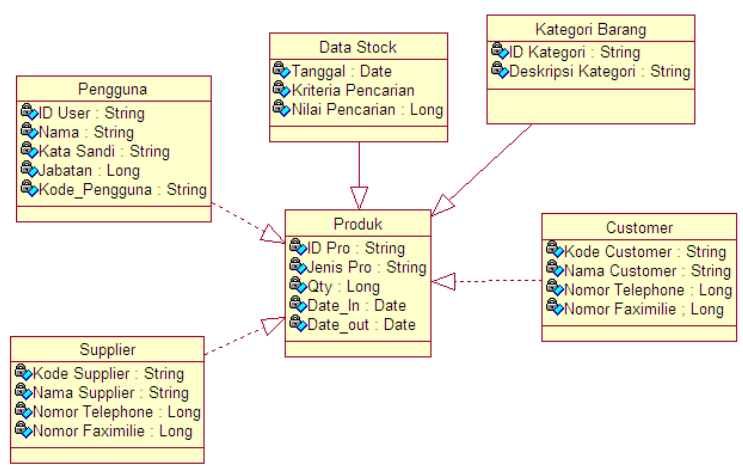

Gambar 5. Class Diagram Aplikasi POS

Gambar 5 diatas merupakan gambar Class Diagram Aplikasi POS yang dibuat. Dalam class diagram ini ada berbagai kelas yang dipakai untuk menampung data dan membuat obyek dalam pemrograman aplikasi ini. Kelas Produk merupakan kelas kunci dimana setiap kelas yang lain, mengacu pada kelas produk.

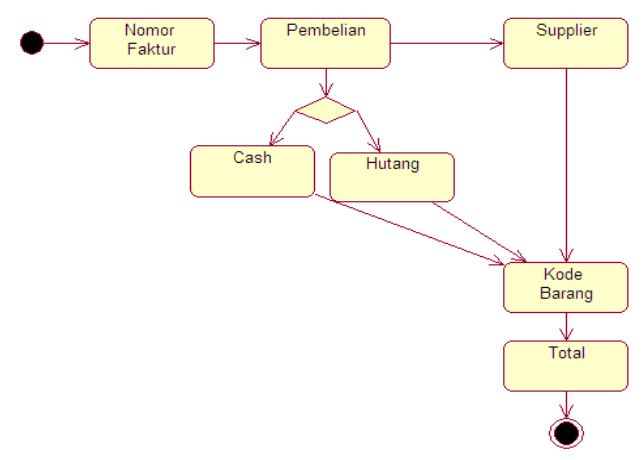

Gambar 6. Activity Diagram Aplikasi POS

Dalam Activity Diagram pada gambar 6 diatas, dimulai dari pembelian yang disertai oleh nomor faktur. Setelah melakukan pembelian, ketahap pembayaran. Pembayaran sendiri sudah dibagi dari berbagai metode pembayarannya. Pembayaran dalam POS ini dibagi menjadi 2 yaitu cash dan hutang. Pada saat yang bersamaan, Supplier akan memberikan kode barang untuk diproses dalam transaksi. Setelah proses transaksi selesai, keluarlah total transaksi seluruhnya.

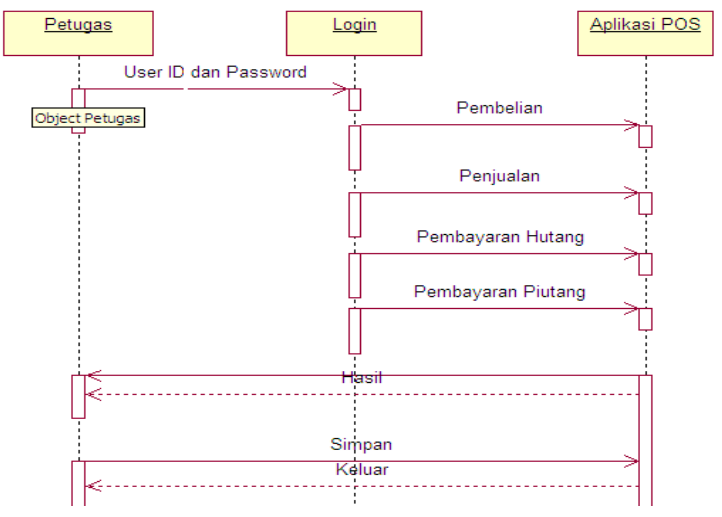

Gambar 7. Sequence Diagram Aplikasi POS

Gambar 7 diatas memperlihatkan bagaimana Aplikasi POS ini digunakan. Petugas disini memberikan Nama Pengguna dan Password kepada Login. Setelah melalui proses autentifikasi, sistem akan memberikan layanan beranda Aplikasi POS kepada petugas. Petugas dapat melakukan pembelian, penjualan, pembayaran utang, dan pembayaran piutang.

\section{PEMBAHASAN}

Dalam penggunaan aplikasi POS ini diperlukan nama pengguna dan password untuk menjaga keamanan dan kredibilitas dari data aplikasi POS. Tampilan antar muka untuk login seperti pada gambar berikut ini:

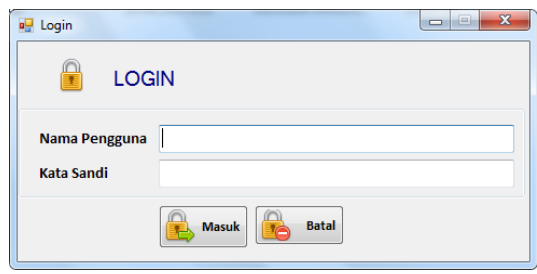

Gambar 8. Tampilan Login Aplikasi POS

Dengan adanya antar muka untuk masuk ke aplikasi POS seperti ini, maka data stok barang hingga penjualan terjaga dengan baik.

\subsection{Berkas}

Dalam menu berkas ini ditujukan untuk mengelola stok barang yang masuk dari supplier, keluar dari kolom pengelolaan stok barang dan 
fasilitas untuk menutup aplikasi POS. Gambar dibawah ini merupakan tampilan antar muka menu berkas dalam aplikasi POS.

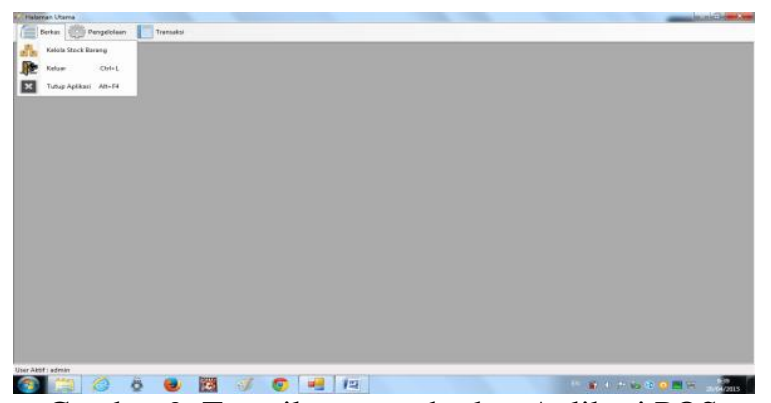

Gambar 9. Tampilan menu berkas Aplikasi POS

\subsection{Pengelolaan}

Pada menu pengelolaan ini digunakan untuk mengelola data pengguna yang akan menggunakan aplikasi POS ini, mengelola data customer yang telah melakukan interaksi dengan aplikasi POS ini, mengelola data supplier yang akan memasok kebutuhan pasokan, mengelola data master barang, mengelola data stok yang ada, mengelola kategori barang, menutup data inventory barang dan melakukan backup database. Gambar 10, dibawah ini merupakan tampilan menu pengelolaan dalam aplikasi POS.

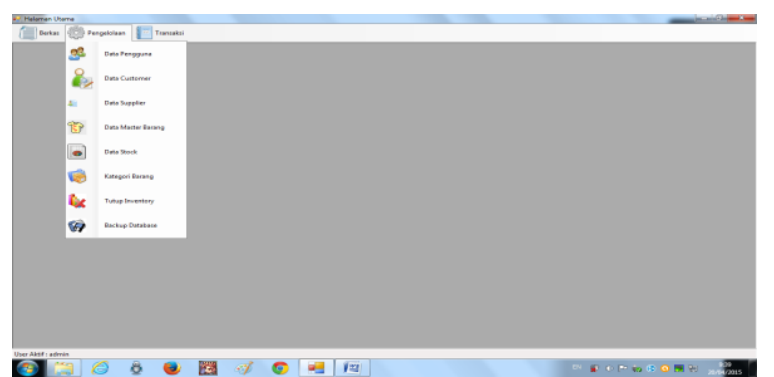

Gambar 10. Tampilan menu pengelolaan Aplikasi POS

Pada gambar 11, terdapat tampilan pengguna. Tampilan pengguna ini digunakan untuk mengelola pengguna / petugas yang akan menggunakan aplikasi ini. Data dalam pengguna ini akan digunakan dalam proses authentifikasi / login yang terdapat pada awal penggunaan aplikasi ini.

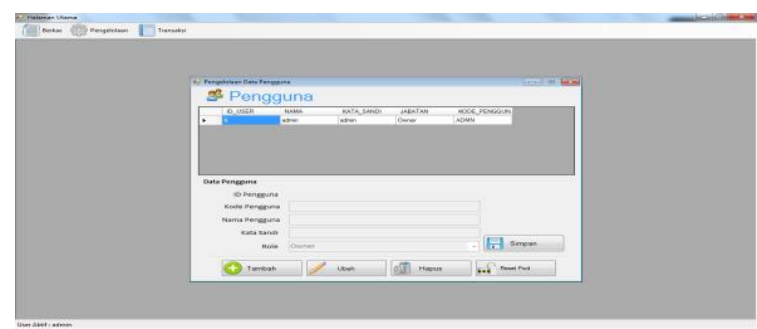

Gambar 11. Tampilan pengguna Aplikasi POS
Pada gambar 12 dibawah ini, terdapat pengelolaan costumer dalam aplikasi POS. Pengelolaan customer / Pelanggan ini untuk mendata pelanggan yang melakukan transaksi.

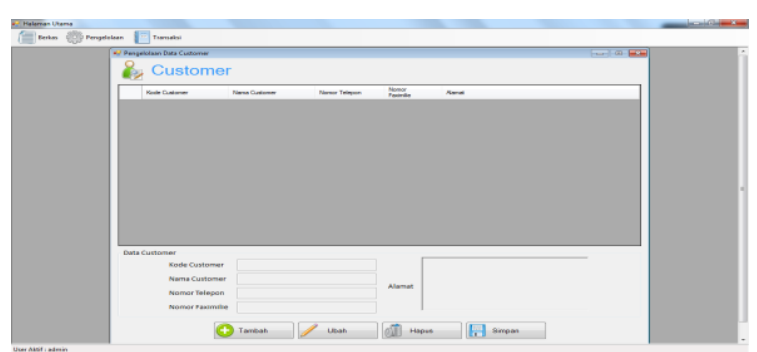

Gambar 12. Tampilan customer Aplikasi POS

Pada gambar 13 dibawah ini, terdapat pengelolaan supplier dalam aplikasi POS. Pengelolaan Supplier/ Pemasok ini untuk mendata pemasok yang melakukan transaksi.

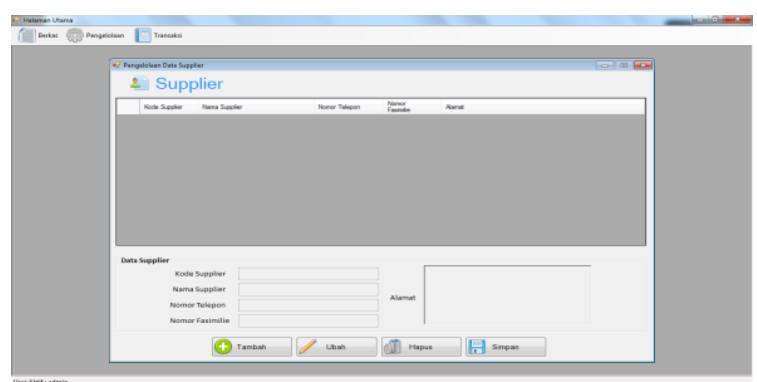

Gambar 13. Tampilan supplier Aplikasi POS

Tampilan data stock Aplikasi POS pada gambar 14, menampilkan jumlah stok barang yang ada. Stok barang dapat dilihat dan dicetak per tanggal yang ditentukan. Selain itu terdapat pula fitur pencarian data dengan berbagai kreteria barang.

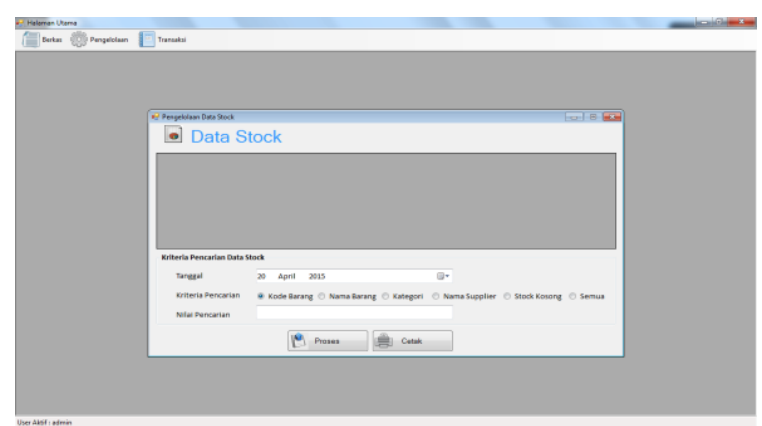

Gambar 14. Tampilan data stock Aplikasi POS

Pada gambar 15, terdapat tampilan kategori barang. Kategori barang ini dibutuhkan sebelum barang dimasukkan. Kategori barang ini digunakan untuk melakukan pemisahan jenis barang. 


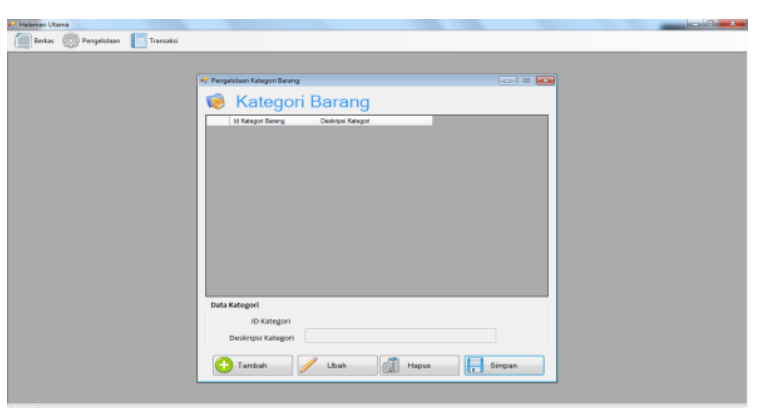

Gambar 15. Tampilan kategori barang Aplikasi POS

Pada gambar 16, terdapat tampilan backup database dari aplikasi POS yang dibangun. Backup database ini bertujuan untuk membuat cadangan data diluar aplikasi sehingga apabila ada sistem error nantinya dalam aplikasi, dapat langsung dikembalikan seperti semula. Adanya fasilitas backup database ini merupakan salah satu dari penerapan Disaster Recovery Plan (DRP).

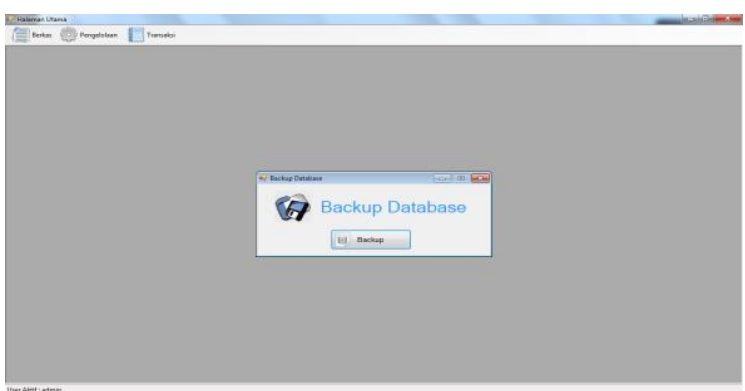

Gambar 16. Tampilan backup database Aplikasi POS

\subsection{Transaksi}

Menu transaksi digunakan untuk mengelola data pembelian yang terjadi, data retur pembelian apabila terjadi pengembalian barang, transaksi penjualan dengan menggunakan user administrator, pembayaran hutang maupun pembayaran piutang dan reporting atau laporan. Gambar dibawah ini merupakan tampilan antar muka menu transaksi dalam aplikasi POS.

Pada gambar 17 dibawah ini, terdapat tampilan pengelolaan pembelian dalam aplikasi POS. Saat menjalankan pengelolaan ini, pengguna memasukkan nomor faktur dan nama supplier dari barang yang kita beli. Setelah itu, pengguna dapat menambahkan barang apa yang telah dibelinya di bagian bawah dari nomor faktur dan nama supplier.

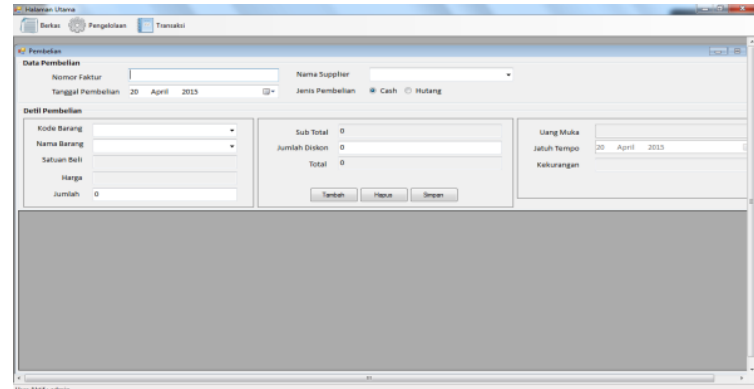

Gambar 17. Tampilan data pembelian Aplikasi POS

Pada gambar 18, terdapat tampilan data retur pembelian dalam aplikasi POS ini. Tampilan ini digunakan kalau ada pembelian yang diretur dalam aplikasi ini.

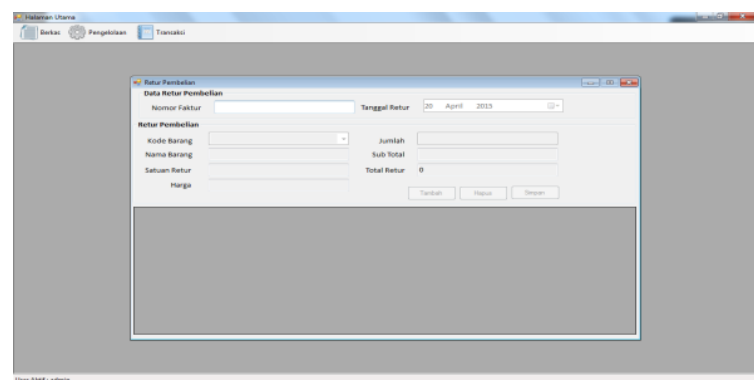

Gambar 18. Tampilan data retur pembelian Aplikasi POS

Gambar 18 dibawah ini menampilkan pengelolaan data penjualan dalam aplikasi POS. Bagian ini paling sering digunakan karena bagian ini merupakan inti dari aplikasi POS. Bagian penjualan ini menampilkan secara urut dan otomatis nomor faktur setiap kali transaksi. Pembayaran transaksipun dapat melalui cash atau utang.

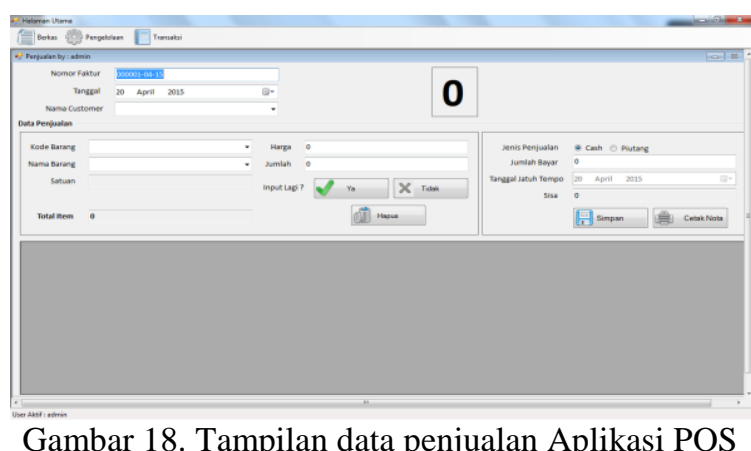

Pada gambar 19, terdapat tampilan hutang aplikasi POS. Tampilan ini hanya menampilkan hutang yang dipunyai oleh toko ini. Pada bagian ini dapat memasukkan tanggal lunas dari hutang yang ada. 
26 Jurnal Teknologi Informasi dan Ilmu Komputer (JTIIK), Vol. 2, No. 1, April 2015, hlm. 20-28

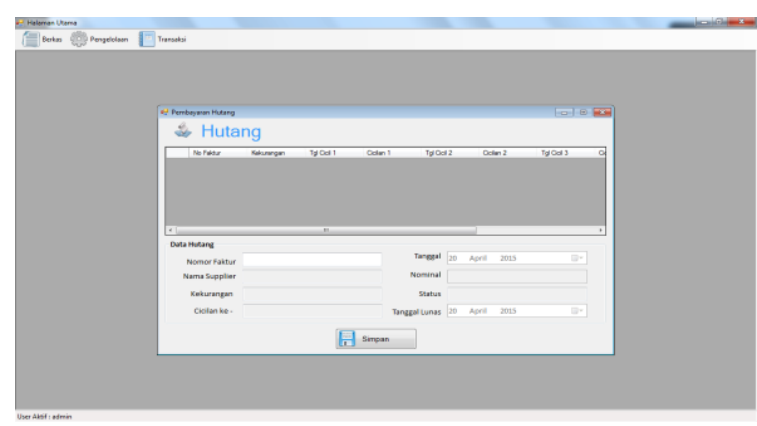

Gambar 19. Tampilan hutang Aplikasi POS

Pada gambar 20, terdapat tampilan piutang aplikasi POS. Tampilan ini hanya menampilkan piutang yang dipunyai oleh toko ini. Pada bagian ini dapat memasukkan tanggal lunas dari piutang yang ada.

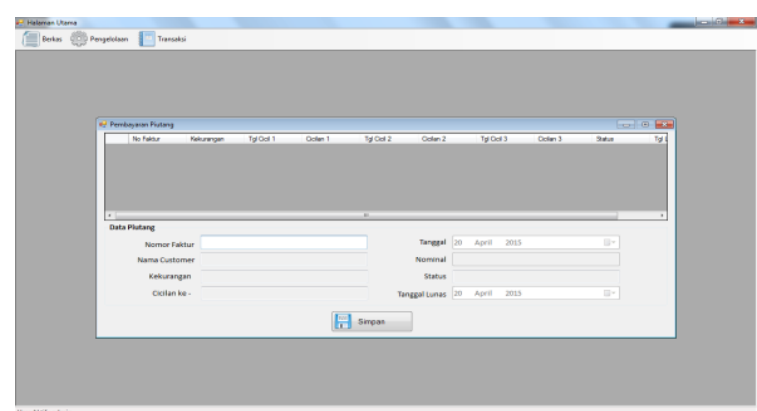

Gambar 20. Tampilan data piutang Aplikasi POS

Pada gambar 21 dibawah ini, terdapat tampilan laporan dalam aplikasi POS. Laporan ini dapat ditampilkan berdasarkan kata kunci atau secara keseluruhan. Selain ditampilkan, aplikasi ini mendukung pencetakan laporan.

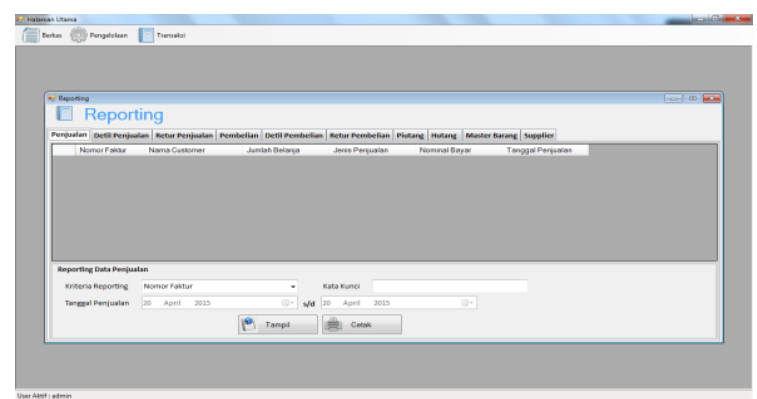

Gambar 21. Tampilan reporting Aplikasi POS

\section{HASIL UJI PERANGKAT LUNAK}

Untuk mendapatkan hasil yang prima dan sesuai dengan yang diharapkan, maka pengujian aplikasi / perangkat lunak wajib dilakukan. Pengujian aplikasi ini dilakukan dengan melakukan pengecekan langsung dalam aplikasi desuaikan dengan rencana pengujian aplikasi. Dalam tabel 1 dibawah, terdapat berbagai rencana pengujian aplikasi sebagai berikut:

Tabel 1. Rencana Pengujian Aplikasi

\begin{tabular}{|l|l|l|}
\hline Kelas Uji & Detail Pengujian & Jenis Uji \\
\hline Tampilan & Menampilkan & Black box \\
\hline
\end{tabular}

\begin{tabular}{|c|c|c|}
\hline Kelas Uji & Detail Pengujian & Jenis Uji \\
\hline Login & tampilan login & \\
\hline $\begin{array}{l}\text { Tampilan } \\
\text { beranda }\end{array}$ & $\begin{array}{l}\text { Menampilkan } \\
\text { tampilan beranda }\end{array}$ & Black box \\
\hline $\begin{array}{l}\text { Tampilan } \\
\text { pengguna }\end{array}$ & $\begin{array}{l}\text { Menampilkan } \\
\text { tampilan pengguna }\end{array}$ & Black box \\
\hline $\begin{array}{l}\text { Tampilan } \\
\text { customer }\end{array}$ & $\begin{array}{l}\text { Menampilkan } \\
\text { tampilan customer }\end{array}$ & Black box \\
\hline $\begin{array}{l}\text { Tampilan } \\
\text { supplier }\end{array}$ & $\begin{array}{l}\text { Menampilkan } \\
\text { tampilan supplier }\end{array}$ & Black box \\
\hline $\begin{array}{l}\text { Tampilan data } \\
\text { stock }\end{array}$ & $\begin{array}{l}\text { Menampilkan } \\
\text { tampilan data stock }\end{array}$ & Black box \\
\hline $\begin{array}{l}\text { Tampilan } \\
\text { kategori } \\
\text { barang }\end{array}$ & $\begin{array}{l}\text { Menampilkan } \\
\text { tampilan kategori } \\
\text { barang }\end{array}$ & Black box \\
\hline $\begin{array}{l}\text { Tampilan } \\
\text { Backup } \\
\text { Database }\end{array}$ & $\begin{array}{l}\text { Menampilkan } \\
\text { tampilan backup } \\
\text { database }\end{array}$ & Black box \\
\hline $\begin{array}{l}\text { Tampilan } \\
\text { Data } \\
\text { Pembelian }\end{array}$ & $\begin{array}{l}\text { Menampilkan } \\
\text { tampilan data } \\
\text { pembelian }\end{array}$ & Black box \\
\hline $\begin{array}{l}\text { Tampilan } \\
\text { Data Retur } \\
\text { Pembelian } \\
\end{array}$ & $\begin{array}{l}\text { Menampilkan } \\
\text { tampilan data retur } \\
\text { pembelian }\end{array}$ & Black box \\
\hline $\begin{array}{l}\text { Tampilan } \\
\text { Data } \\
\text { Penjualan }\end{array}$ & $\begin{array}{l}\text { Menampilkan } \\
\text { tampilan data } \\
\text { penjualan }\end{array}$ & Black box \\
\hline $\begin{array}{l}\text { Tampilan } \\
\text { Hutang }\end{array}$ & $\begin{array}{l}\text { Menampilkan } \\
\text { tampilan hutang }\end{array}$ & Black box \\
\hline $\begin{array}{l}\text { Tampilan } \\
\text { Piutang } \\
\end{array}$ & $\begin{array}{l}\text { Menampilkan } \\
\text { tampilan Piutang }\end{array}$ & Black box \\
\hline $\begin{array}{l}\text { Tampilan } \\
\text { Reporting }\end{array}$ & $\begin{array}{l}\text { Menampilkan } \\
\text { tampilan laporan }\end{array}$ & Black box \\
\hline
\end{tabular}

Dari rencana yang didapat di tabel 4 diatas, maka dapat dilakukan beberapa tahap pengujian sebagai berikut :

Tabel 2. Pengujian Tampilan Login

\begin{tabular}{|l|l|l|}
\hline \multicolumn{3}{|c|}{ Hasil Uji } \\
\hline $\begin{array}{l}\text { Data } \\
\text { Masukan }\end{array}$ & Hasil yang diharapkan & Kesimpulan Uji \\
\hline $\begin{array}{l}\text { Nama } \\
\text { Pengguna } \\
\text { benar dan } \\
\text { password } \\
\text { benar }\end{array}$ & $\begin{array}{l}\text { Menampilkan notifikasi sukses } \\
\text { dan selamat datang pengguna. }\end{array}$ & Handal \\
\hline $\begin{array}{l}\text { Nama } \\
\text { Pengguna } \\
\text { benar dan } \\
\text { password } \\
\text { salah }\end{array}$ & Menampilkan notifikasi gagal & \\
\hline $\begin{array}{l}\text { Nama } \\
\text { Pengguna } \\
\text { salah dan } \\
\text { password } \\
\text { benar }\end{array}$ & Menampilkan notifikasi gagal & Handal \\
\hline $\begin{array}{l}\text { Nama } \\
\text { Pengguna } \\
\text { salah dan } \\
\text { password } \\
\text { salah }\end{array}$ & login. & \\
\hline
\end{tabular}

Tabel 3. Pengujian Tampilan Beranda

\begin{tabular}{|l|l|l|}
\hline \multicolumn{3}{|c|}{ Hasil Uji } \\
\hline $\begin{array}{l}\text { Data } \\
\text { Masukan }\end{array}$ & Hasil yang diharapkan & Kesimpulan Uji \\
\hline $\begin{array}{l}\text { notifikasi } \\
\text { sukses dari } \\
\text { tampilan }\end{array}$ & Menampilkan tampilan beranda & Handal \\
login & & \\
\hline
\end{tabular}

Tabel 4. Pengujian Tampilan Pengguna

\begin{tabular}{|l|l|l|}
\hline \multicolumn{3}{|c|}{ Hasil Uji } \\
\hline $\begin{array}{l}\text { Data } \\
\text { Masukan }\end{array}$ & Hasil yang diharapkan & Kesimpulan Uji \\
\hline
\end{tabular}


Permana, dkk, Analisa dan Perancangan Aplikasi POS untuk Mendukung Manajemen.. 27

\begin{tabular}{|l|l|l|}
\hline Klik & Menyimpan data yang telah terisi & Handal \\
tombol & & \\
tambah, & & \\
data terisi & & \\
dan tekan & & \\
tombol & & \\
simpan & & Handal \\
\hline $\begin{array}{l}\text { Pilih data } \\
\text { dan tekan }\end{array}$ & Menghapus data & \\
tombol & & \\
hapus & & Handal \\
\hline $\begin{array}{l}\text { Pilih data } \\
\text { dan tekan } \\
\text { tombol edit }\end{array}$ & Menyimpan data yang telah & \\
\hline $\begin{array}{l}\text { Pilih data } \\
\text { dan tekan }\end{array}$ & Mengubah password dan & Handal \\
tombol & menyimpan password baru & \\
reset & & \\
password & & \\
\hline
\end{tabular}

Tabel 5. Pengujian Tampilan costumer

\begin{tabular}{|l|l|l|}
\hline \multicolumn{3}{|c|}{ Hasil Uji } \\
\hline $\begin{array}{l}\text { Data } \\
\text { Masukan }\end{array}$ & Hasil yang diharapkan & Kesimpulan Uji \\
\hline $\begin{array}{l}\text { Klik } \\
\text { tombol } \\
\text { tambah, } \\
\text { data terisi } \\
\text { dan tekan } \\
\text { tombol }\end{array}$ & Menyimpan data yang telah terisi & Handal \\
simpan & & \\
\hline $\begin{array}{l}\text { Pilih data } \\
\text { dan tekan } \\
\text { tombol }\end{array}$ & Menghapus data & \\
hapus & & \\
\hline $\begin{array}{l}\text { Pilih data } \\
\text { dan tekan } \\
\text { tombol edit }\end{array}$ & Menyimpan data yang telah & Handal \\
\hline
\end{tabular}

Tabel 6. Pengujian Tampilan supplier

\begin{tabular}{|c|c|c|}
\hline \multicolumn{3}{|c|}{ Hasil Uji } \\
\hline $\begin{array}{l}\text { Data } \\
\text { Masukan }\end{array}$ & Hasil yang diharapkan & Kesimpulan Uji \\
\hline $\begin{array}{l}\text { Klik } \\
\text { tombol } \\
\text { tambah, } \\
\text { data terisi } \\
\text { dan tekan } \\
\text { tombol } \\
\text { simpan }\end{array}$ & Menyimpan data yang telah terisi & Handal \\
\hline $\begin{array}{l}\text { Pilih data } \\
\text { dan tekan } \\
\text { tombol } \\
\text { hapus }\end{array}$ & Menghapus data & Handal \\
\hline $\begin{array}{l}\text { Pilih data } \\
\text { dan tekan } \\
\text { tombol edit }\end{array}$ & $\begin{array}{l}\text { Menyimpan data yang telah } \\
\text { diubah }\end{array}$ & Handal \\
\hline
\end{tabular}

Tabel 7. Pengujian Tampilan Data Stock

\begin{tabular}{|l|l|l|}
\hline \multicolumn{3}{|c|}{ Hasil Uji } \\
\hline $\begin{array}{l}\text { Data } \\
\text { Masukan }\end{array}$ & Hasil yang diharapkan & Kesimpulan Uji \\
\hline $\begin{array}{l}\text { Klik } \\
\text { tombol } \\
\text { proses }\end{array}$ & Menampilkan data stock barang & Handal \\
\hline $\begin{array}{l}\text { Klik } \\
\text { tombol } \\
\text { cetak }\end{array}$ & Mencetak data stock barang & Handal \\
\hline
\end{tabular}

Tabel 8. Pengujian Tampilan Kategori Barang

\begin{tabular}{|c|c|c|}
\hline \multicolumn{3}{|c|}{ Hasil Uji } \\
\hline $\begin{array}{l}\text { Data } \\
\text { Masukan }\end{array}$ & Hasil yang diharapkan & Kesimpulan Uji \\
\hline $\begin{array}{l}\text { Klik } \\
\text { tombol } \\
\text { tambah, } \\
\text { data terisi }\end{array}$ & Menyimpan data yang telah terisi & Handal \\
\hline
\end{tabular}

\begin{tabular}{|l|l|l|}
\hline $\begin{array}{l}\text { dan tekan } \\
\text { tombol } \\
\text { simpan }\end{array}$ & & \\
\hline $\begin{array}{l}\text { Pilih data } \\
\text { dan tekan } \\
\text { tombol } \\
\text { hapus }\end{array}$ & Menghapus data & \\
\hline $\begin{array}{l}\text { Pilih data } \\
\text { dan tekan } \\
\text { tombol edit }\end{array}$ & $\begin{array}{l}\text { Menyimpan data yang telah } \\
\text { diubah }\end{array}$ & \\
\hline
\end{tabular}

Tabel 9. Pengujian Tampilan Backup Database

\begin{tabular}{|l|l|l|}
\hline \multicolumn{3}{|c|}{ Hasil Uji } \\
\hline $\begin{array}{l}\text { Data } \\
\text { Masukan }\end{array}$ & Hasil yang diharapkan & Kesimpulan Uji \\
\hline $\begin{array}{l}\text { Klik } \\
\text { tombol } \\
\text { backup }\end{array}$ & $\begin{array}{l}\text { Sistem melakukan backup seluruh } \\
\text { data }\end{array}$ & Handal \\
\hline
\end{tabular}

Tabel 10. Pengujian Tampilan Data Pembelian

\begin{tabular}{|l|l|l|}
\hline \multicolumn{3}{|c|}{ Hasil Uji } \\
\hline $\begin{array}{l}\text { Data } \\
\text { Masukan }\end{array}$ & Hasil yang diharapkan & Kesimpulan Uji \\
\hline $\begin{array}{l}\text { Klik } \\
\text { tombol } \\
\text { tambah, } \\
\text { data terisi } \\
\text { dan tekan }\end{array}$ & Menyimpan data yang telah terisi & Handal \\
tombol & & \\
simpan & & \\
\hline $\begin{array}{l}\text { Pilih data } \\
\text { dan tekan } \\
\text { tombol }\end{array}$ & Menghapus data & \\
hapus & & Handal \\
\hline $\begin{array}{l}\text { Pilih data } \\
\text { dan tekan } \\
\text { tombol edit }\end{array}$ & Menyimpan data yang telah & \\
\hline
\end{tabular}

Tabel 11. Pengujian Tampilan Data Retur Pembelian

\begin{tabular}{|c|c|c|}
\hline \multicolumn{3}{|c|}{ Hasil Uji } \\
\hline $\begin{array}{l}\text { Data } \\
\text { Masukan }\end{array}$ & Hasil yang diharapkan & Kesimpulan Uji \\
\hline $\begin{array}{l}\text { Isi nomor } \\
\text { faktur, } \\
\text { Klik } \\
\text { tombol } \\
\text { tambah, } \\
\text { data terisi } \\
\text { dan tekan } \\
\text { tombol } \\
\text { simpan }\end{array}$ & Menyimpan data yang telah terisi & Handal \\
\hline $\begin{array}{l}\text { Isi nomor } \\
\text { faktur, } \\
\text { pilih data } \\
\text { dan tekan } \\
\text { tombol } \\
\text { hapus }\end{array}$ & Menghapus data & Handal \\
\hline $\begin{array}{l}\text { Isi nomor } \\
\text { faktur, } \\
\text { pilih data } \\
\text { dan tekan } \\
\text { tombol edit }\end{array}$ & $\begin{array}{l}\text { Menyimpan data yang telah } \\
\text { diubah }\end{array}$ & Handal \\
\hline
\end{tabular}

Tabel 12. Pengujian Tampilan Data Penjualan

\begin{tabular}{|l|l|l|}
\hline \multicolumn{3}{|c|}{ Hasil Uji } \\
\hline $\begin{array}{l}\text { Data } \\
\text { Masukan }\end{array}$ & Hasil yang diharapkan & Kesimpulan Uji \\
\hline Mengisi & Menyimpan data yang telah terisi & Handal \\
data, Klik & & \\
tombol & & \\
tambah, & & \\
data terisi & & \\
dan tekan & & \\
tombol & & \\
simpan & & Handal \\
\hline Pilih data & Menghapus data & \\
\hline
\end{tabular}




\begin{tabular}{|l|l|l|}
\hline $\begin{array}{l}\text { dan tekan } \\
\text { tombol } \\
\text { hapus }\end{array}$ & & \\
\hline $\begin{array}{l}\text { Tekan } \\
\text { tombol } \\
\text { mencetak }\end{array}$ & Mencetak data yang telah dipilih & Handal \\
nota & & \\
\hline
\end{tabular}

Tabel 13. Pengujian Tampilan Hutang

\begin{tabular}{|l|l|l|}
\hline \multicolumn{3}{|c|}{ Hasil Uji } \\
\hline $\begin{array}{l}\text { Data } \\
\text { Masukan }\end{array}$ & Hasil yang diharapkan & Kesimpulan Uji \\
\hline $\begin{array}{l}\text { Mengisi } \\
\text { nomor } \\
\text { faktur dan } \\
\text { tanggal }\end{array}$ & Menyimpan tanggal yang telah & Handal \\
lunas & & \\
\hline
\end{tabular}

Tabel 14. Pengujian Tampilan Piutang

\begin{tabular}{|l|l|l|}
\hline \multicolumn{3}{|c|}{ Hasil Uji } \\
\hline $\begin{array}{l}\text { Data } \\
\text { Masukan }\end{array}$ & Hasil yang diharapkan & \\
\hline Mengisi & Menyimpulan Uji \\
nomor & terisi & Handal \\
faktur dan & & \\
tanggal & & \\
lunas & & \\
\hline
\end{tabular}

Tabel 15. Pengujian Tampilan Reporting

\begin{tabular}{|l|l|l|}
\hline \multicolumn{3}{|c|}{ Hasil Uji } \\
\hline $\begin{array}{l}\text { Data } \\
\text { Masukan }\end{array}$ & Hasil yang diharapkan & Kesimpulan Uji \\
\hline $\begin{array}{l}\text { Tekan } \\
\text { tampil }\end{array}$ & Menampilkan laporan & Handal \\
\hline $\begin{array}{l}\text { Tekan } \\
\text { tombol } \\
\text { Cetak }\end{array}$ & Mencetak laporan & \\
\hline $\begin{array}{l}\text { Mengisi } \\
\text { kata kunci } \\
\text { dan } \\
\text { menekan } \\
\text { tombol } \\
\text { tampil }\end{array}$ & $\begin{array}{l}\text { Menampilkan laporan yang sesuai } \\
\text { dengan kata kunci }\end{array}$ & Handal \\
\hline $\begin{array}{l}\text { Mengisi } \\
\text { kata kunci } \\
\text { dan } \\
\text { menekan } \\
\text { tombol } \\
\text { cetak }\end{array}$ & $\begin{array}{l}\text { Mencetak laporan yang sesuai } \\
\text { dengan kata kunci }\end{array}$ & \\
\hline
\end{tabular}

\section{KESIMPULAN}

Rancangan aplikasi point of sales (POS) ini mampu mengatasi permasalahan dan dapat menyajikan informasi secara lebih baik dan terkomputerisasi. Dengan diterapkannya aplikasi point of sales (POS) ini dapat membantu tugas-tugas pihak-pihak terkait atau seluruh stakeholder yang berhubungan langsung dengan aplikasi POS ini. Aplikasi POS ini didesain dengan antar muka interaktif sehingga baik administasi maupun pemilik dapat langsung menggunakan aplikasi POS ini dengan sebaik-baiknya.

\section{DAFTAR PUSTAKA}

AXOPOS. 2012. Point Of Sale, http://www.axopos.com/article/point-ofsale-71.html (diakses 27 April 2015).

GINTORO, EDWIN, 2008. Perancangan Aplikasi Point Of Sales Berbasiskan Customer
Relationship Management Pada Toko Buku Notre-Dame. Jurnal CommIT, Vol. 2 No. 1 Mei 2008 Teknik Informatika, Fakultas Ilmu Komputer, Universitas Bina Nusantara. (diakses 27 April 2015)

HARIS KLANA SANIF, 2010. Pengaruh Penerapan Aplikasi POS (Point Of Sale) Berbasis Komputer Terhadap Kecepatan Proses Transaksi Penjualan Dan Pembelian. Laporan karya ilmiah|Tugas Akhir| Fakultas Ekonomi Universitas Jember 2010. (diakses 27 April 2015)

HARTONO, PETRUS, 2009. Analisis Dan Perancangan Aplikasi Point Of Sales Yang Terhubung Dengan Electronic Data Capture. Laporan karya ilmiah|Tugas Akhir| Program Studi Teknik Informatika, Fakultas Ilmu Komputer, Universitas Bina Nusantara. (diakses 27 April 2015)

IMANUEL ABDI RIDARTA GINTING, 2011, Rancangan \& Implementasi Point Of Sales (POS) Berbasis Web Pada Distro Previous. Laporan Naskah Publikasi|Tugas Akhir| Program Studi Sistem Informasi STMIK AMIKOM Yogyakarta (diakses 27 April 2015)

JOGIYANTO 2008, Analisis dan Desain Sistem Informasi, Andi Offset, Yogyakarta.

NOVITA, 2014, Perancangan Sistem Informasi Point Of Sale (POS) Pada PD.Tokyo. Laporan karya ilmiah|Tugas Akhir| Program Studi Sistem Informasi STMIK MDP 2014. (diakses 27 April 2015)

PERMANA, SILVESTER DIAN HANDY. 2014. Analisis dan Perancangan Sistem Informasi Toko Dika. Seminar Nasional|Prosiding Seminar Nasional Literasi Informasi (SENARAI). ISBN 979-458-762-1 Senarai 2014 Medan Universitas Sumatera Utara 1 Desember 2014.

TRIO RULIA WINDA AFRIANTO, 2010, Analisis dan Implementasi Sistem Informasi Pembelian dan Penjualan Menggunakan Model Reuse-Oriented Berbasis Framework AHADPOS. Laporan karya ilmiah | Tugas Akhir | Program Studi Teknologi Informasi dan Ilmu Komputer Universitas Brawijaya Malang. (diakses 27 April 2015)

WIDIANTO, 2013, Perancangan Sistem Point of Sales (POS) Pada Toko Koperasi Jasa Pakarti Semarang (PT. Jasa Marga Tbk Cabang Semarang). Laporan karya ilmiah | Tugas Akhir| Program Studi Sistem Informasi| Fakultas Ilmu Komputer | Universitas Dian Nuswantoro Semarang | 2013. (diakses 27 April 2015) 